\title{
Mechanical properties of mortar produced with the replacement of natural sand by scheelite residue
}

\section{(Propriedades mecânicas de argamassa produzida com substituição da areia natural por resíduo de scheelita)}

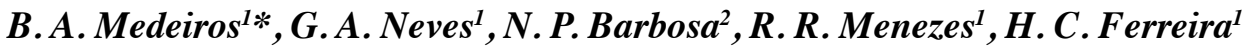 \\ ${ }^{1}$ Universidade Federal de Campina Grande, Programa de Pós-Graduação em Ciência e \\ Engenharia de Materiais, Av. Aprígio Veloso 882, 58429-900, Campina Grande, PB, Brazil \\ ${ }^{2}$ Universidade Federal da Paraíba, Programa de Pós-Graduação em Ciência e Engenharia de Materiais, \\ 58051-900, João Pessoa, PB, Brazil
}

\begin{abstract}
The residue generated by industrial activities represents a cost, since the generators are responsible for its management, transportation, treatment and disposal. Rio Grande do Norte State in Brazil is the greatest producer of scheelite residue. The aim of this research was to characterize this mining residue, identify its similarity with natural sand and produce a coating mortar with it. In the composition of mortar, a Brazilian Portland cement type CPII-F32 and an industrialized calcium hydroxide as a binder were used. Laser granulometry, bulk and relative density, EDX, XRD and thermal analysis were done to obtain a physical and chemical characterization of the residue. Mechanical tests (tensile bond strength and compressive strength), SEM and water absorption test were done to analyze the behavior of mortar. All tests confirmed that mechanical properties were according to standards for tile mortar.
\end{abstract}

Keywords: mining residue, scheelite characterization, mechanical property, mortar.

\section{Resumo}

O resíduo gerado pelas atividades industriais representa um custo, já que os geradores são responsáveis pela sua gestão, transporte, tratamento e disposição. O estado do Rio Grande do Norte, Brasil, é o maior produtor de resíduos de scheelita. O objetivo desta pesquisa foi caracterizar este resíduo de mineração, identificar sua similaridade com areia natural e produzir uma argamassa de revestimento. Na composição das argamassas foram empregados o cimento Portland tipo CPII-F32 e o hidróxido de cálcio industrializado como ligante. Granulometria a laser, densidade aparente e relativa, EDX, DRX e análise térmica foram realizadas para a caracterização física e química do resíduo. Testes mecânicos (resistência de aderência à tração e resistência à compressão), MEV e teste de absorção de água foram realizados para analisar o comportamento da argamassa. Os testes realizados confirmaram que as propriedades mecânicas estavam em acordo com padrões de argamassa de revestimento.

Palavras-chave: resíduo industrial, scheelita, caracterização, propriedade mecânica, argamassa.

\section{INTRODUCTION}

The ceramic sector stands out because of the great potential to absorb various types of industrial waste, thus contributing to the preservation of the environment. There are two main reasons why countries recycle their industrial waste: i) the depletion of the stocks of raw materials; and ii) the increasing volume of solid waste [1]. The use of recycled materials in sectors such as ceramic industry represents a current concern with the issue of sustainability, but it can also reverse benefits in financial matters. The concern with fees and charges for the disposal of waste produced, as well as the possibility of saving the budget worksheet, causes

*prof.brunna.almeida@gmail.com

(D) https://orcid.org/0000-0003-0474-0818 interest in some investors to encourage researches that solve these problems. Researchers have studied the reduction of the consumption of clay, a non-renewable natural resource [2], and the incorporation of residue in ceramic tile composition $[3,4]$. What remains to prove the effectiveness of the use of recycled aggregates is the certainty about the actual gains of the builders and the quality of the product manufactured [5].

The scheelite waste used in this research was collected from a mining complex located in the State of Rio Grande do Norte, Northeast of Brazil. The production of this mine corresponds to 20 tons per month, and for each ton, $250 \mathrm{~kg}$ of scheelite concentrate and $750 \mathrm{~kg}$ of waste are generated. There is an estimated 4.0 to 4.5 million tons of scheelite residue [6]. According to [6], these reserves grew $3.6 \%$ on average per year. In Brazil, the largest tungsten explorers from the scheelite are in the State of Rio Grande do Norte, in the Serido region, which accounts for about $70 \%$ of the 
40 thousand tons recorded in 2010. The Brazilian mineral production, calculated by IBRAM [7] for 2016, was US\$ 24 billion, $7.6 \%$ lower than in 2015 . It was observed that the production volumes of the mining companies in Brazil remained largely stable, however, the price variation of major commodities throughout 2016 signaled a reduction in annual value [7]. In 2017 a slight recovery was estimated at US\$ 25 billion [7]. The Brazilian Ministry of Development, Industry and Foreign Trade also registered a growth of the sector in the last decades but highlighted that over the years the mineral activity has suffered a reduction due to the socioeconomic changes that have occurred in the country. The use of waste produced in this sector for its use in civil construction has also intensified over the years.

According to [8], the sector of ornamental stone processing was faced with environmental issues, which stimulated the search for viable alternatives for the deposition of this waste produced. Still, according to the authors, construction is one of the largest explorers of natural resources, the sector can become a potential agent of absorption of industrial and urban waste. Moura et al. [9] carried out research with the incorporation of the residue from Cariri stone to produce conventional concrete. The use of industrial waste in building materials is very common. Gunning et al. [10] investigated the effects of carbonation on seventeen different types of industrial waste, including municipal solid waste, fly ash, incinerated hospital waste ash, biomass ash, wood ash, paper mud, etc. Incorporation of different types of waste in mortar and concrete with different function has been studied in several recent researches [11-13]. Replacement of regular materials in concrete and mortar composition, like natural sand or cement [14-16], and analyses of the behavior of mechanical properties of mortar and concrete made with waste [17-20] have also been investigated. Yemam et al. [18] analyzed the behavior of mortars produced with the use of sand washing waste as potential filler for epoxy resin mortar. Kim et al. [19] analyzed the mechanical characterization of high-performance steel-fiber reinforced cement composites with the use of very fine silica sand instead of normal sand. Sampaio et al. [21] characterized concrete containing residues of porcelain tile polishing, tire rubber and limestone, and Leonel et al. [22] characterized soil-cement bricks with the incorporation of used foundry sand. Based on the environmental aspect, Argane et al. [23] studied the incorporation of mining tailings as aggregate in mortars. The authors analyzed the mechanical and durability behavior of mortar and concluded that the use of mine tailings may become a sustainable alternative method for construction materials. The use of concrete and masonry residue in the production of aggregates was the aim of the study in several researches. Evangelista et al. [24] investigated the use of concrete residue in the production of aggregates, comparing it with two types of natural aggregates. Fan at al. [25] concluded that the benefits of using recycled concrete as aggregate must be balanced against the increased impact on the environment and Torres-Gómez et al. [26] combined effects of fly ash and recycled masonry on mortar properties to reduce cement and natural resource consumption. In this way, the quality and durability of the materials should be carefully analyzed and should be the aim of different researches in building materials. The aim of this study was to characterize the scheelite mining residue, identify its similarity with natural sand and produce a tile mortar with it.

\section{MATERIALS AND METHODS}

Scheelite waste was collected from dunes in the mining complex, located in the municipality of Currais Novos, in Rio Grande do Norte State, Brazil. The cement used in the research was Portland cement type CPII-F32, classified by standard NBR 11578:1997 [27], which contained an addition of limestone filer, and a class CH-I calcium hydroxide as a binder. The physical characterization of the residue is fundamental to produce a correct composition of mortar and concrete, such as the amount of aggregates, binders, water and additives. Whereas mostly aggregate samples hold heterogeneous characteristics, the sampling process aimed to reduce the collected sample into a more homogeneous possible amount according to the standard NBR NM 27:2001 [28]. Laser granulometry, bulk density [29] and relative density [30] were performed. In addition to these tests, chemical analysis was done to identify the composition of the waste (energy-dispersive X-ray fluorescence spectrometry, EDX-720, Shimadzu, and X-ray diffraction, XRD, Miniflex 600, Rigaku) and microanalysis by scanning electron microscopy, SEM. To identify the metals presenting in the residue it was necessary to obtain extracts by leaching or solubilization of the sample following the procedures indicated in the standard NBR 10006:2004 [31], and using atomic absorption spectrometry. The thermal analysis had the purpose of identifying the behavior of the residue when submitted to high temperatures (up to $1000{ }^{\circ} \mathrm{C}$ ). The analysis was performed using BP RB-3000 equipment, with a heating rate of $12.5^{\circ} \mathrm{C} / \mathrm{min}$ until $1000^{\circ} \mathrm{C}$.

After the procedures of characterization, it was possible to define the proportions used for molding the mortar specimens. For the reference experiments, the proportions used were only with cement, calcium hydroxide and natural sand ( $0 \%$ of substitution). The other mixtures replaced $100 \%$ of the natural sand by the residue with different proportions of materials. The proportions in volume used for tile mortar were 1:2:8, 1:2:9 and 1:2:10 (cement: calcium hydroxide: fine aggregate) [32]. The produced mortar followed the mixture proportions defined according to Table I. Two tests in fresh mortar were done, a flow table test [33] which verified the consistency and workability of mortar and the other test was mass density [34] made immediately after the preparation of the mortar. The air incorporated in the mortar was calculated from the density checked in the fresh state.

The hardened mortar should develop sufficient strength to a defined purpose or a stipulated loading without failure [35]. The process of molding and curing of the specimens followed the NBR 13279:2005 [36], for evaluation of the behavior of the specimen in tensile and compressive 
Table I - Three different compositions of mortar with $100 \%$ residue replacing the fine aggregate.

[Tabela I - Três diferentes composições da argamassa com 100\% de substituição de agregado fino por resíduo.]

\begin{tabular}{ccccc}
\hline Composition & Ratio & Cement & $\begin{array}{c}\text { Calcium } \\
\text { hydroxide }\end{array}$ & $\begin{array}{c}\text { Aggregate } \\
\text { (residue) }\end{array}$ \\
\hline \multirow{2}{*}{ T128 } & Volume & 1 & 2 & 8 \\
& Mass & 1.00 & 0.71 & 9.09 \\
\multirow{2}{*}{ T129 } & Volume & 1 & 2 & 9 \\
& Mass & 1.00 & 0.71 & 10.22 \\
\multirow{2}{*}{ T1210 } & Volume & 1 & 2 & 10 \\
& Mass & 1.00 & 0.71 & 11.36 \\
\hline
\end{tabular}

loadings. Immediately after mixing, the mortar was shaped in $4 \times 4 \times 16 \mathrm{~cm}$ prismatic molds. For the curing process, the molds remained between 24 and $48 \mathrm{~h}$ at $23 \pm 2{ }^{\circ} \mathrm{C}$ and relative humidity of $60 \% \pm 5 \%$; after this period, the specimens were unmolded and maintained in the same environment until the day of the tests. The bulk density of the hardened mortar was also verified after the period of curing. Tensile strength in flexure and compressive strength were determined according to the standard NBR 13279:2005 [36]. Both tests were performed on the same specimen, thus ensuring greater efficiency in obtaining the results. The standard recommends that the tests should be performed with a 28-day-old specimen, but for this research, a 7-day cure was also adopted. According to this standard [36], the maximum absolute deviation of the specimens tested must be calculated. For axial compression tests, the maximum absolute deviation shall not exceed $0.5 \mathrm{MPa}$. If this occurs, a new test should be taken with at least new four specimens. The standard NBR 15259:2005 [37] establishes the equipment and procedures for the water absorption test by capillarity and the determination of the capillary coefficient of the mortar. The 28-day-old specimens were sanded with thick sandpaper and cleaned with a brush to determine the initial mass. The specimens were then positioned with the square face on a constant water sheet with $5 \mathrm{~mm}$ above the face in contact with water. After placing the specimens in contact with the water, the mass was checked at 10 and 90 min of testing. The capillary coefficient was obtained approximately through the difference between the mass means at 10 and 90 min and expressed in $\mathrm{g} . \mathrm{dm}^{-2} \cdot \mathrm{min}^{-1 / 2}$. The maximum relative deviation of the series of specimens was calculated and expressed as a percentage. Similar to strength results, if the deviation was greater than $20 \%$, a new mean should be calculated by neglecting the discrepant value and adopting a new mean with at least two specimens. The pull-off test verifies the maximum stress that mortar can withstand without losing its adhesion to the stresses acting on the substrate interface. Standard NBR 15258:2005 [38] establishes the conditions and equipment necessary to carry out this test. The substrate coated with the mortar was submitted to a curing process of 28 days in an external environment subjected to climatic conditions, such as temperature changes throughout the day. About three days before the desired age, the fixing and cutting of the specimens that underwent the pull out were carried out. In accordance with the standard, ten test specimens spaced at least $40 \mathrm{~mm}$ from the edges and $20 \mathrm{~mm}$ apart were tested; the equipment that measured the tensile force was then coupled to each insert. After the pull-out, the rupture load, the surface area of each test specimen and the way the rupture occurred were recorded. The rupture type was classified as substrate rupture (S), substrate/mortar interface rupture (S/A), rupture in the mortar (A) and failure of the glue on the insert $(\mathrm{F})$.

\section{RESULTS AND DISCUSSION}

Residue characterization: the relative and bulk densities of the residue were 2.90 and $1.67 \mathrm{~g} / \mathrm{cm}^{3}$, respectively. These values were higher than natural sand whose relative density was $2.63 \mathrm{~g} / \mathrm{cm}^{3}$. The average diameter obtained through the laser granulometry was $22.37 \mu \mathrm{m}$. Granulometry is fundamental for the dosing process and can directly influence the amount of water required, the porosity and, in turn, the strength and durability of the mortar produced. Thermogravimetry (TG) of the scheelite residue is shown in Fig. 1. Analyzing the TG curve, at $100{ }^{\circ} \mathrm{C}$ the residue presented a mass loss of $0.8 \%$ due to the presence of free water. The mass loss of approximately $18 \%$ between 600 and $850{ }^{\circ} \mathrm{C}$ corresponded to the decomposition of calcium and magnesium carbonates. The calcium oxide content (Table II) was due to the calcite present in the residue, which was confirmed by EDX in Fig. 2. In addition, the mass loss was also represented by the decomposition of the hydroxides present in the scheelite sample. The most evidenced mass loss from $700{ }^{\circ} \mathrm{C}$ could correspond to a loss of hydroxyls, then the decomposition to oxides.

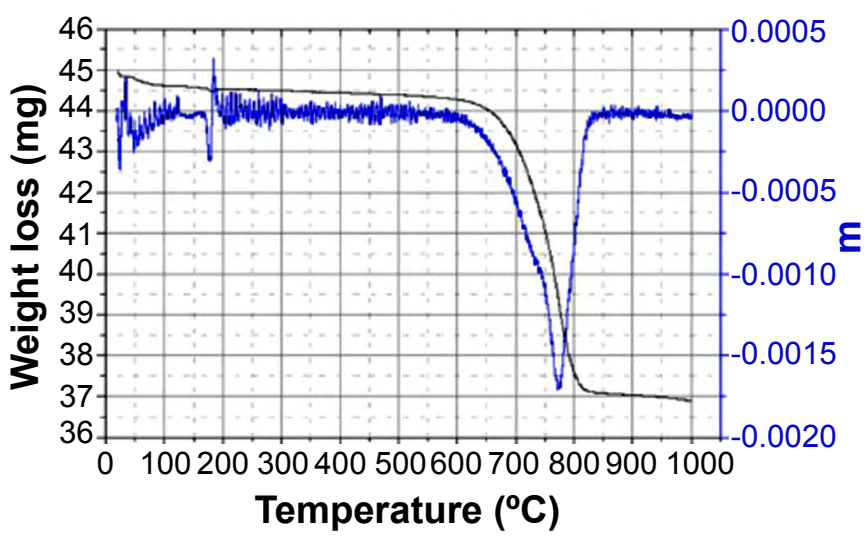

Figure 1: Thermogravimetry curves of scheelite residue.

[Figura 1: Curvas termogravimétricas do resíduo de scheelita.]

Analyzing the chemical composition by EDX, high contents of calcium oxide $(\mathrm{CaO}>47 \%)$ and silica $\left(\mathrm{SiO}_{2}>26 \%\right)$ were observed in the residue. Alumina $\left(\mathrm{Al}_{2} \mathrm{O}_{3}\right)$ content was higher than 9\% (Table II). In Fig. 2, it was verified that the residue was composed of the following mineralogical phases: quartz $\left(\mathrm{SiO}_{2}\right)$, characterized by PDF 
Table II - Chemical composition (wt\%) of scheelite residue (as collected).

[Tabela II - Composição química (\% em massa) do resíduo de scheelita (como coletado).]

\begin{tabular}{cccccccc}
\hline $\mathrm{CaO}$ & $\mathrm{SiO}_{2}$ & $\mathrm{Al}_{2} \mathrm{O}_{3}$ & $\mathrm{Fe}_{2} \mathrm{O}_{3}$ & $\mathrm{Sc}_{2} \mathrm{O}_{3}$ & $\mathrm{MgO}$ & $\mathrm{WO}_{3}$ & Other oxides \\
\hline 47.30 & 31.82 & 9.75 & 6.57 & - & 2.46 & 0.15 & 1.93 \\
\hline
\end{tabular}

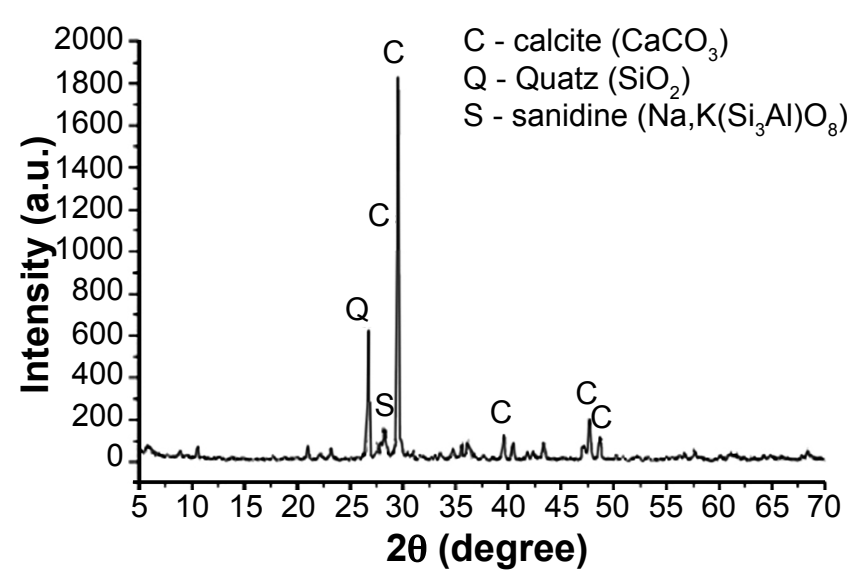

Figure 2: X-ray diffraction pattern of scheelite residue.

[Figura 2: Difratograma de raios $X$ do resíduo de scheelita.]

file $\mathrm{N}^{\circ} 46-1045$; calcite $\left(\mathrm{CaCO}_{3}\right)$, characterized by the PDF file $\mathrm{N}^{\circ} 5-0586$; and sanidine $\left(\mathrm{NaKSi}_{3} \mathrm{Al}\right)$ characterized by the PDF file $\mathrm{N}^{\circ} 10-0357$. The highest XRD peaks (quartz and calcite) coincided with the diffractograms found in the literature but the smaller peaks differed with the presence of diopside [6]. The results obtained by atomic absorption spectrometry of the leached and solubilized extracts of the sample indicated that the scheelite residue did not present high levels of metals in the collected sample. The values of barium (Ba), aluminum (Al), copper $(\mathrm{Cu})$, manganese $(\mathrm{Mn})$, iron $(\mathrm{Fe})$ and zinc $(\mathrm{Zn})$ were quantified and the values obtained and the parameters established by the standard are shown in Table III. Analyzing secondary electron images from SEM (Fig. 3), it was possible to identify the similarity of grain morphology between natural sand and scheelite residue. Both grains had rounded shape which is one of the most important information to identify aggregates in SEM
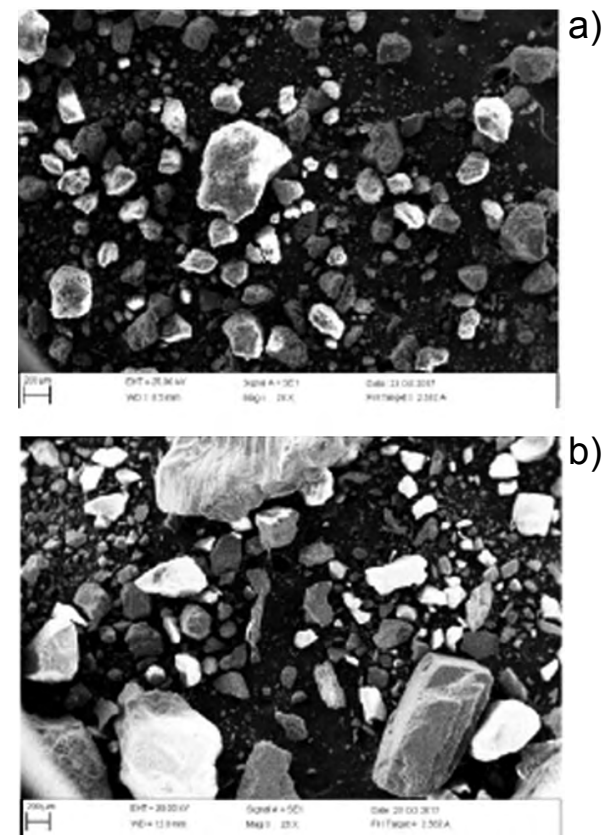

Figure 3: SEM images showing the similarity between natural sand (a) and scheelite residue (b).

[Figura 3: Imagens de MEV mostrando a similaridade entre a areia natural (a) e o resíduo de scheelita (b).]

images of mortar. Natural sand had more homogeneous particle size while scheelite waste had grains with broader particle sizes. Calcite could be identified by its grey level, brighter than silica.

Produced mortar: flow table test was carried out to verify the consistency of each composition of mortar produced. No plasticizing additives were used, so the water was added until the mortar obtained the recommended consistency of

Table III - Values obtained by the spectrometry and parameters established by the standard.

[Tabela III - Valores obtidos por espectrometria e os parâmetros estabelecidos pela norma.]

\begin{tabular}{ccccc}
\hline Parameter & $\begin{array}{c}\text { Leached } \\
\text { extract }(\mathrm{mg} / \mathrm{L})\end{array}$ & $\begin{array}{c}\text { Maximum limit* } \\
(\mathrm{mg} / \mathrm{L})\end{array}$ & $\begin{array}{c}\text { Solubilized } \\
\text { extract }(\mathrm{mg} / \mathrm{L})\end{array}$ & $\begin{array}{c}\text { Maximum } \\
\text { limit* }(\mathrm{mg} / \mathrm{L})\end{array}$ \\
\hline $\mathrm{Ba}$ & 0.69 & 70.00 & $<0.10$ & 0.70 \\
$\mathrm{Al}$ & $<0.10$ & - & $<0.10$ & 0.20 \\
$\mathrm{Cu}$ & 0.55 & - & 0.01 & 2.00 \\
$\mathrm{Mn}$ & 1.15 & - & 0.04 & 0.10 \\
$\mathrm{Fe}$ & 0.07 & - & $<0.01$ & 0.30 \\
$\mathrm{Zn}$ & 0.02 & - & 0.08 & 5.00 \\
Sulphates $\left(\mathrm{SO}_{4}^{2-}\right)$ & 101.50 & - & 131.90 & 250 \\
Chlorides $\left(\mathrm{Cl}^{-}\right)$ & 525.40 & - & 503.40 & 250 \\
\hline *- ABNT NBR 10004 standard. & & & &
\end{tabular}


$260 \mathrm{~mm}$ of spread. Thus, the consistency indexes for the three traces resulted in values between 258 and $261 \mathrm{~mm}$ (range allowed by the standard). The water/cement ratio was $2.25,2.00$ and 2.64 , respectively, for T128, T129 and T1210 compositions. After determining the amount of

Table IV - Density and incorporated air content in different mortar compositions.

[Tabela IV - Densidade e ar incorporado em diferentes composições da argamassa.]

\begin{tabular}{ccc}
\hline Composition & $\begin{array}{c}\text { Fresh density } \\
\left(\mathrm{g} / \mathrm{cm}^{3}\right)\end{array}$ & $\begin{array}{c}\text { Incorporated } \\
\text { air content }(\%)\end{array}$ \\
\hline $\mathrm{T} 128$ & 2.30 & 10.50 \\
$\mathrm{~T} 129$ & 2.42 & 6.92 \\
$\mathrm{~T} 1210$ & 2.46 & 6.10 \\
\hline
\end{tabular}

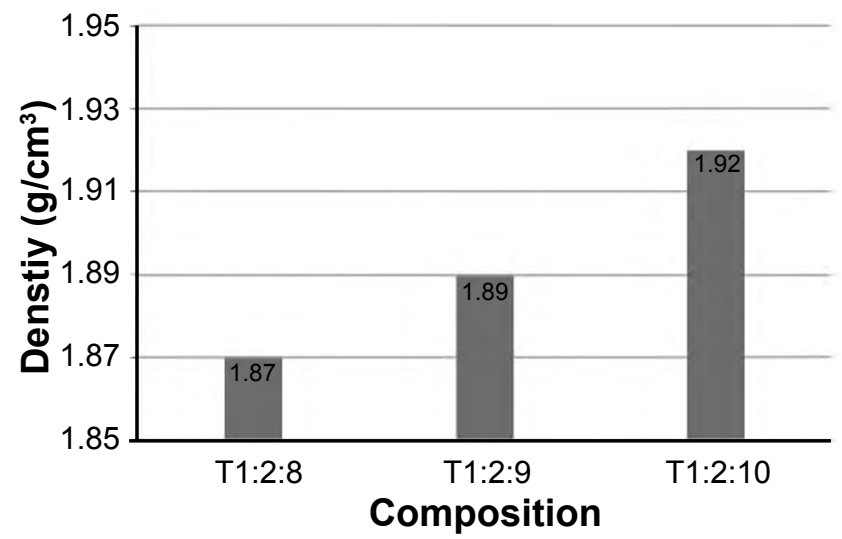

Figure 4: Density in hardened state of three composition of mortar produced.

[Figura 4: Densidade no estado endurecido de três composições de argamassas produzidas.]

Table V - Results of tensile strength in flexure and compressive strength.

[Tabela $V$ - Resultados de resistências à tração na flexão e compressão.]

\begin{tabular}{|c|c|c|c|c|c|c|c|}
\hline \multirow{2}{*}{ Composition } & \multirow{2}{*}{ Specimen } & $\begin{array}{l}\text { Tensile strength } \\
\text { in flexure (MPa) }\end{array}$ & \multicolumn{2}{|c|}{$\begin{array}{l}\text { Compressive } \\
\text { strength }(\mathrm{MPa})\end{array}$} & $\begin{array}{l}\text { Tensile strength } \\
\text { in flexure (MPa) }\end{array}$ & \multicolumn{2}{|c|}{$\begin{array}{l}\text { Compressive } \\
\text { strength }(\mathrm{MPa})\end{array}$} \\
\hline & & \multicolumn{3}{|c|}{ 7-days-old } & \multicolumn{3}{|c|}{ 28-days-old } \\
\hline \multirow{6}{*}{$\mathrm{T} 128$} & A & 0.89 & 2.79 & 2.80 & 1.19 & 3.30 & 3.31 \\
\hline & B & 0.88 & 2.84 & 2.84 & 0.93 & 3.24 & 3.23 \\
\hline & $\mathrm{C}$ & 0.88 & 2.82 & 2.81 & 1.05 & 3.05 & 3.04 \\
\hline & $\mathrm{D}$ & 0.88 & 2.80 & 2.81 & 1.14 & 3.07 & 3.06 \\
\hline & E & 0.87 & 2.80 & 2.80 & 0.98 & 3.16 & 3.17 \\
\hline & $\mathrm{F}$ & 0.89 & 2.78 & 2.79 & 1.14 & 3.24 & 3.23 \\
\hline \multicolumn{2}{|c|}{ Average } & 0.88 & \multicolumn{2}{|c|}{2.80} & 1.07 & \multicolumn{2}{|c|}{3.17} \\
\hline \multicolumn{2}{|c|}{ Standard deviation } & $0.01-0.01$ & \multicolumn{2}{|c|}{$0.02-0.40$} & $0.12-0.14$ & \multicolumn{2}{|c|}{$0.12-0.14$} \\
\hline \multirow{6}{*}{ T129 } & $\mathrm{A}$ & 0.83 & 2.68 & 2.67 & 0.98 & 3.05 & 3.04 \\
\hline & B & 0.83 & 2.65 & 2.64 & 1.10 & 3.04 & 3.04 \\
\hline & $\mathrm{C}$ & 0.82 & 2.63 & 2.63 & 0.93 & 2.94 & 2.93 \\
\hline & $\mathrm{D}$ & 0.84 & 2.70 & 2.71 & 0.89 & 3.06 & 3.05 \\
\hline & $\mathrm{E}$ & 0.84 & 2.65 & 2.64 & 0.91 & 3.04 & 3.02 \\
\hline & $\mathrm{F}$ & 0.82 & 2.66 & 2.66 & 0.91 & 3.03 & 3.04 \\
\hline \multicolumn{2}{|c|}{ Average } & 0.83 & \multicolumn{2}{|c|}{2.66} & 0.95 & \multicolumn{2}{|c|}{3.02} \\
\hline \multicolumn{2}{|c|}{ Standard deviation } & $0.01-0.01$ & \multicolumn{2}{|c|}{$0.03-0.05$} & $0.06-0.15$ & \multicolumn{2}{|c|}{ 0.04-0.09 } \\
\hline \multirow{6}{*}{ T1210 } & A & 0.79 & 2.20 & 2.22 & 0.86 & 2.94 & 2.95 \\
\hline & B & 0.78 & 2.12 & 2.11 & 0.93 & 2.93 & 2.94 \\
\hline & $\mathrm{C}$ & 0.78 & 2.23 & 2.23 & 0.93 & 2.95 & 2.93 \\
\hline & $\mathrm{D}$ & 0.75 & 2.19 & 2.18 & 0.91 & 2.99 & 2.98 \\
\hline & $\mathrm{E}$ & 0.79 & 2.19 & 2.19 & 0.84 & 2.94 & 2.93 \\
\hline & $\mathrm{F}$ & 0.78 & 1.98 & 2.05 & 0.86 & 2.94 & 2.95 \\
\hline \multicolumn{2}{|c|}{ Average } & 0.77 & \multicolumn{2}{|c|}{2.15} & 0.89 & \multicolumn{2}{|c|}{2.94} \\
\hline \multicolumn{2}{|c|}{ Standard deviation } & $0.02-0.02$ & \multicolumn{2}{|c|}{$0.17-0.08$} & $0.04-0.05$ & \multicolumn{2}{|c|}{$0.01-0.05$} \\
\hline
\end{tabular}


Table VI: Results of water absorption and capillarity test.

[Tabela VI: Resultados do ensaio de absorção e capilaridade.]

\begin{tabular}{cccc}
\hline Composition T129 & $\begin{array}{c}\text { Absorption at } \\
10 \min \left(\mathrm{g} / \mathrm{cm}^{2}\right)\end{array}$ & $\begin{array}{c}\text { Absorption at } \\
90 \min \left(\mathrm{g} / \mathrm{cm}^{2}\right)\end{array}$ & $\begin{array}{c}\text { Capillary coefficient } \\
\left(\mathrm{g} / \mathrm{dm}^{2} / \mathrm{min}^{1 / 2}\right)\end{array}$ \\
\hline A & 0.14 & 0.36 & 7.2 \\
$\mathrm{~B}$ & 0.15 & 0.36 & 7.6 \\
$\mathrm{C}$ & 0.13 & 0.33 & 7.0 \\
$\mathrm{D}$ & 0.14 & 0.35 & 7.6 \\
$\mathrm{E}$ & 0.16 & 0.42 & 8.4 \\
$\mathrm{~F}$ & 0.13 & 0.35 & 7.5 \\
Average & 0.14 & 0.36 & 7.55 \\
Maximum & $14.3 \%$ & $11.7 \%$ & $11.3 \%$ \\
absolute deviation & & & \\
\hline
\end{tabular}

water required for each composition, the fresh density test was performed. Analyzing the values in Table IV, there was an increase in density in the fresh state proportional to the decrease of the binder/dry material ratio. The incorporated air content in each composition showed a decrease in relation to the increase in the amount of dry material. The higher the binder/dry material ratio, the higher was the percentage of incorporated air found in the mixture. By relating incorporated air content to the density of each composition, the values were inversely proportional; the denser the composition, the less the amount of air incorporated in the mixture. The high values of incorporated air content foment the viability of the mortars but could compromise the mechanical strength, since they increase the porosity of the mixtures. The use of additives appears as an alternative to increase the content of incorporated air without damaging the strength of the mortars. The values found $(\leq 10 \%)$ led to the decision not to use additives, but were still considered satisfactory for this research, as they ensured the viability of the mortars.

The results of density in the hardened state are shown in Fig. 4, and it is possible to identify a small increase in density for composition that had the lowest binder/dry material ratio. This result was already expected according to the results of density in the fresh state, justifying the T1210 as the mortar with the highest density, because it had a higher quantity of aggregate in its composition. Tensile and compressive strength tests were performed on the same specimens after 7 and 28 days of curing. Six replicates were tested for each mortar composition, a total of 18 specimens. Table V shows the results obtained individually, the average of each composition and the standard deviation. The results obtained were considered valid since they had absolute deviations lower than the maximums allowed for the tests of tensile strength in flexure and compressive strength $(0.30$ and $0.50 \mathrm{MPa}$, respectively). The composition T129 was adopted for all next tests because it presented more satisfactory mechanical results than T1210 and more economical than T128, which had a higher binder/aggregate ratio.

In Table VI the water absorption and capillary coefficient values of the test specimens incorporated with residues after curing of 28 days are shown. One of the specimens presented values well above the average, which resulted in an increase in the maximum absolute deviation. However, according to the Brazilian standard [36], a new average should be calculated only if the deviation was greater than $20 \%$. The average of water absorption was $0.14 \mathrm{~g} / \mathrm{cm}^{2}$ at $10 \mathrm{~min}$ and $0.36 \mathrm{~g} / \mathrm{cm}^{2}$ at 90 min (Table VI).

A masonry of ceramic blocks measuring $1 \times 1 \mathrm{~m}$ coated with the first layer of cement paste was prepared to perform

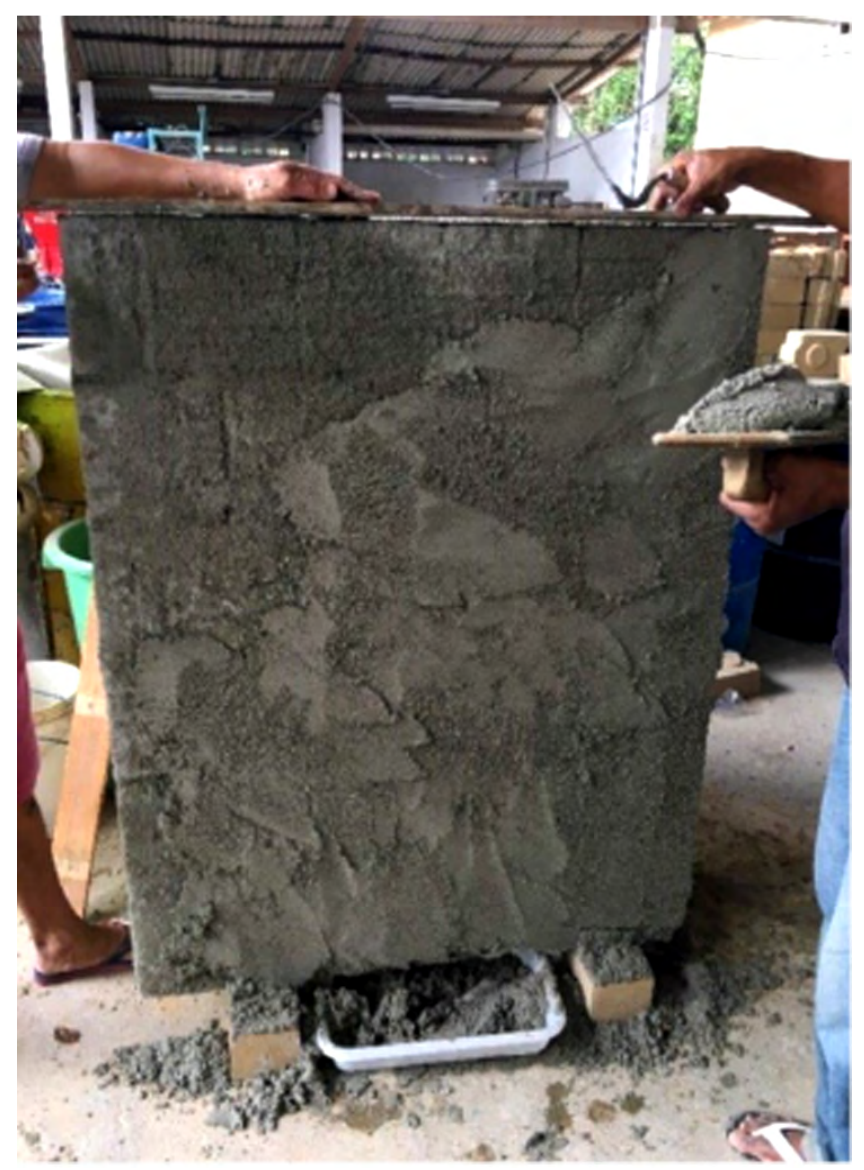

Figure 5: Masonry of ceramic blocks coated with mortar with scheelite residue.

[Figura 5: Alvenaria de blocos cerâmicos revestida com argamassa com resíduo de scheelita.] 
the tensile bond strength test using the composition T129 (Fig. 5). The mortar was applied to the substrate in two layers with approximately $5 \mathrm{~mm}$ each. After the uniformization and regularization of the surface, the masonry was placed in the curing process for 28 days. The values recorded during the tensile bond strength test are presented in Table VII; the highlighted value was disregarded because it was outside the $30 \%$ margin of the average, and the specimens with no value suffered some damage during the test and were also neglected. The test was also done using natural sand and the results presented in Table VII show a similarity between the two types of mortar (with and without substitution) presenting an average of 0.23 and $0.22 \mathrm{MPa}$, respectively. Another characteristic observed in the bond test was the way the rupture occurred. The rupture could occur in the substrate (S), substrate/mortar interface (S/A) and mortar (A). Most of the specimens submitted to the test suffered rupture in the mortar (A), and only the specimen 12 had a

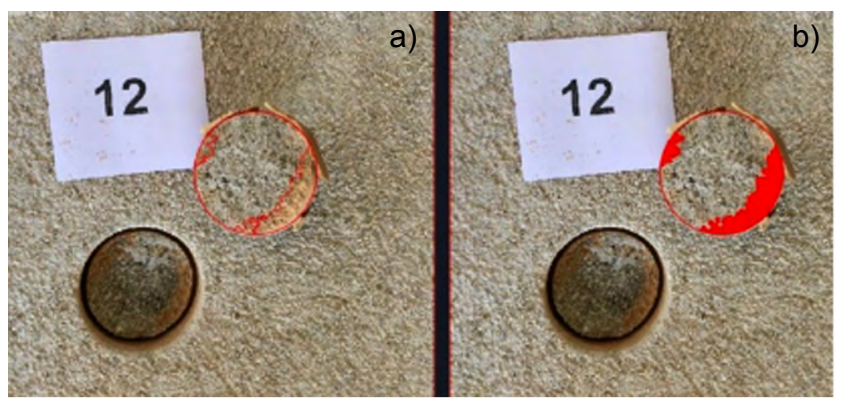

Figure 6: Details of the surface of the specimen that ruptured in the substrate.

[Figura 6: Detalhes da superfície do corpo de prova que rompeu no substrato.] partial rupture in the substrate. To verify the percentage of the area that had ruptured in the substrate, the images and perimeter were analyzed with the aid of AutoCAD software, Fig. 6. It was found that $4.13 \mathrm{~cm}^{2}$ of the surface area of the specimen ruptured in the substrate, approximately $20 \%$ of its surface area. The fact that most of the ruptures occurred in the mortar and not in the substrate indicated that the coating layer cannot be very thick, since it could cause detachment.

SEM images using secondary electron of mortars with natural sand and with $100 \%$ replacement of aggregate by scheelite residue are shown in Figs. $7 \mathrm{a}$ and $7 \mathrm{~b}$, respectively. In these images, cement hydration products (rough surface) and particles of aggregate (smoother surface) could be identified. In Fig. $7 \mathrm{~b}$ the surface was rougher than in Fig. $7 \mathrm{a}$, which could indicate the reduction of voids in the cement paste associated with the ages of the samples. The sample with scheelite residue was prepared 15 days before the sample with natural sand. Furthermore, it was concluded that both mortars (with
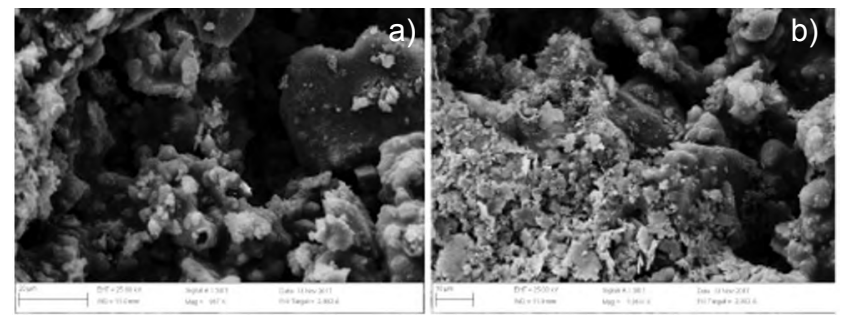

Figure 7: SEM images showing different phases of mortar with natural sand (a) and with $100 \%$ replacement of aggregate by scheelite residue (b).

[Figura 7: Imagens de MEV mostrando diferentes fases da argamassa com areia natural (a) e com $100 \%$ de substituição do agregado por resíduo de scheelita $(b)$.]

Table VII - Results of the tensile bond test.

[Tabela VII - Resultados do ensaio de adesão.]

\begin{tabular}{|c|c|c|c|c|}
\hline \multirow[t]{2}{*}{ Specimen } & Weight (kgf) & Strength $(\mathrm{MPa})$ & Weight (kgf) & Strength $(\mathrm{MPa})$ \\
\hline & \multicolumn{2}{|c|}{ With scheelite aggregate } & \multicolumn{2}{|c|}{ With natural sand } \\
\hline 1 & 57 & 0.28 & 60 & 0.29 \\
\hline 2 & 24 & 0.11 & 35 & 0.16 \\
\hline 3 & 35 & 0.17 & 39 & 0.19 \\
\hline 4 & 39 & 0.19 & - & - \\
\hline 5 & 57 & 0.28 & 37 & 0.18 \\
\hline 6 & 57 & 0.28 & 48 & 0.23 \\
\hline 7 & - & - & 47 & 0.24 \\
\hline 8 & 48 & 0.23 & 57 & 0.28 \\
\hline 9 & 47 & 0.23 & 24 & 0.11 \\
\hline 10 & - & - & - & - \\
\hline 11 & 60 & 0.29 & 57 & 0.28 \\
\hline 12 & 60 & 0.29 & 58 & 0.28 \\
\hline \multicolumn{2}{|c|}{ Maximum deviation } & 0.30 & & 0.28 \\
\hline \multicolumn{2}{|c|}{ Average } & 0.23 & & 0.22 \\
\hline \multicolumn{2}{|c|}{ Minimum deviation } & 0.16 & & 0.15 \\
\hline
\end{tabular}


natural sand and with residue) presented a similar chemical reaction with the components of the cement.

\section{CONCLUSIONS}

After characterization of the scheelite mining waste, it was possible to figure out that the residue had chemical and physical characteristics very similar to natural sand. All the tests confirmed that the results for the mechanical properties were according to standards for tile mortar and it could be used as fine aggregate to replace natural sand. The next steps will be the analyzes of the durability of mortar to identify harmful agents within its microstructure, for example, expansive components that could produce an alkali-aggregate reaction.

\section{ACKNOWLEDGMENTS}

The authors would like to acknowledge the mining complex of Tomaz Salustiano S.A. which provided all residue used in this research, LABEME (Construction and Building Material of Federal University of Paraíba-UFCG) and its staffs for helping with mechanical tests, the Environmental Management and Waste Treatment Laboratory (LABGER) of UFCG, the Characterization Laboratory of Material Engineering of UFCG which provided the tests of EDX, XRD and Thermogravimetry, CAPES for the financial support, Australian Center of Microscopy and Microanalysis (University of Sydney) for the training and use of microscopes and a special acknowledgment to Federal Institute of Paraíba for allowing the author Brunna Almeida leaving her professional activities during this research.

\section{REFERENCES}

[1] G.A. Neves, R.R. Menezes, H.C. Ferreira, Brazil. J. Agric. Environ. Eng. 6 (2002) 303.

[2] J.P.D. Vitorino, S.N. Monteiro, C.M.F. Vieira, Cerâmica 55, 336 (2009) 385.

[3] R.R. Menezes, L.N. Marques, L.N.L. Santana, R.H.G.A. Kiminami, G.A. Neves, H.S. Ferreira, Cerâmica 56, 339 (2010) 244.

[4] L.A. Freitas, S.N. Monteiro, R. Sanchez, C.M.F. Vieira, Cerâmica 57, 342 (2011) 206.

[5] G.L. Vieira, D.C. Dal Molin, Built Environ. 4 (2004) 47.

[6] T.G. Machado, Mater. Sci. Forum 727 (2012) 844.

[7] Braz. Inst. Min., "Annual activity report", Brasilia (2017).

[8] J.P.V.T. Manhaes, J.N.F. Holanda, New Chem. 31 (2008) 1301.

[9] W.A. Moura, M.B. Leite, A.J.O. Bastos, Built Environ. 13 (2013) 7.

[10] P.J. Gunning, C.D. Hills, P.J. Carey, Waste Manage. 30 (2010) 1081.

[11] S.B. Breitenbach, O.C. Santos, J.C.S. Andrade, R.M. Nascimento, A.E. Martinelli, Cerâmica 63, 367 (2017) 395.

[12] R.R. Medeiros, W.P. Gonçalves, J.M. Cartaxo, H.S.
Ferreira, G.A. Neves, H.C. Ferreira, Cerâmica 63, 366 (2017) 134.

[13] O. Aksogan, H. Binici, E. Ortlek, Constr. Build. Mater. 106 (2016) 253.

[14] A. Schackow, D. Stringari, L. Senff, S.L. Correia, A.M. Segadães, Cement Conc. Comp. 62 (2015) 82.

[15] H. Binici, T. Shah, O. Aksogan, H. Kaplan, J. Mater. Process. Technol. 208 (2008) 299.

[16] C.B. Cheah, M. Ramli, Constr. Build. Mater. 30 (2012) 320.

[17] P. Sikora, A. Augustyniak, K. Cendrowski, E. Horszczaruk, T. Rucinska, P. Nawrotek, E. Mijowska, Materials 9 (2016) 701.

[18] D.M. Yeman, B. Kim, J. Moon, C. Yi, Materials 10 (2017) 246.

[19] D.J. Kim, S.H. Kang, T. Ahn, Materials 7 (2014) 508.

[20] M. Zahedi, A.A. Ramezanianpour, A.M. Ramezanianpour, Const. Build. Mater. 78 (2015) 354.

[21] Z.L.M. Sampaio, A.E. Martinelli, T.S. Gomes, Cerâmica 63, 368 (2017) 530.

[22] R.F. Leonel, M.V. Folgueras, L.V.O. Dalla Valentina, S.R. Prim, G.A. Prates, J.C. Caraschi, Cerâmica 63, 367 (2017) 329.

[23] R. Argane, M. Benzaazoua, R. Hakkou, A. Bouamrane, Constr. Build. Mater. 96 (2015) 296.

[24] L. Evangelista, M. Guedes, J. de Brito, A.C. Ferro, M.F. Pereira, Constr. Build. Mater. 86 (2015) 178.

[25] C. Fan, R. Huang, H. Hwang, S. Chao, Materials 8 (2015) 2658.

[26] A.I. Torres-Gómez, E.F. Ledesma, R. Otero, J.M. Fernández, J.R. Jiménez, J. Brito, Materials 9 (2016) 729.

[27] ABNT NBR 11578, "Portland composite cement specification", Braz. Ass. Techn. Stand., Rio Janeiro (1997). [28] ABNT NM 27, "Aggregates - reducing field samples to laboratory testing size", Braz. Ass. Techn. Stand., Rio Janeiro (2001).

[29] ASTM C29, "Standard test method for bulk density ("unit weight") and voids in aggregate", Am. Soc. Test. Mater., West Conshohocken (2017).

[30] ASTM C128, "Standard test method for relative density (specific gravity) and absorption of fine", Am. Soc. Test. Mater., West Conshohocken (2015).

[31] ABNT NBR 10006, "Procedure for obtainment of solubilized extraction of solid wastes", Braz. Ass. Techn. Stand., Rio Janeiro (2004).

[32] F.A. Recena, Knowing mortar, $2^{\text {nd }}$ ed., EDIPUCRS, Porto Alegre (2012) 147.

[33] ABNT NBR 13276, "Mortars applied on walls and ceilings - determination of the consistence index", Braz. Ass. Techn. Stand., Rio Janeiro (2016).

[34] ABNT NBR 13278, "Mortars applied on walls and ceilings - determination of specific gravity and the air entrained content in fresh stage", Braz. Ass. Techn. Stand., Rio Janeiro (2005).

[35] ASTM C125, "Standard terminology relating to concrete and concrete aggregates", Am. Soc. Test. Mater., West Conshohocken (2016). 
[36] ABNT NBR 13279, "Mortars applied on walls and ceilings - determination of the flexural and the compressive strength in the hardened stage", Braz. Ass. Techn. Stand., Rio Janeiro (2005).

[37] ABNT NBR 15259, "Mortars applied on walls and ceilings - determination of water absorption coefficient due to capillary action", Braz. Ass. Techn. Stand., Rio Janeiro (2005).

[38] ABNT NBR 15258 "Mortars applied on walls and ceilings - determination of tensile bond strength", Braz. Ass. Techn. Stand., Rio Janeiro (2005).

(Rec.08/08/2018, Rev.08/11/2018, 16/01/2019, 08/03/2019, Ac. 09/03/2019) 